\title{
SYMBOLISM AT THE PERIPHERY: YEATS, MAETERLINCK, AND CULTURAL NATIONALISM
}

\section{Raphael Ingelbien}

Modernism has been one of the most contested categories of English literary history. Over the last two decades, reputations have been challenged, ideologies have been questioned, and the very concept of an "English modernism" has given way to views that stress the importance of national contexts in the relation that modernist texts bear to history. It has become increasingly difficult to speak of "English modernism" as though it were a "British" or "Anglo-Saxon" category that includes names which were usually lumped together: Eliot, Joyce, Pound, Woolf, Yeats, etc. ${ }^{1}$ Irish literature scholars in particular have been keen to reclaim Yeats and Joyce as part of a distinctively Irish version of modernism, sometimes analyzing their works through postcolonial theory. ${ }^{2}$ The postcolonial challenge and the devolutionary process that affect the canon of English-speaking modernism strike at the very root of what was originally meant by the term: indeed, cosmopolitanism and internationalism were long supposed to be hallmarks of modernism. Those qualities have not been completely discarded, but their nature and scope have been re-examined in the light of modernist writers' involvement in the cultural politics of specific nations.

One aspect of modernist internationalism, however, clearly continues to operate unchanged in most readings. The impact of French symbolism has featured in most definitions of English-speaking modernism-in discussions of modern poetry in English, the terms "symbolism" and "modernism" are often virtually synonymous. ${ }^{3}$ Edmund Wilson's ground-breaking study, Axël's Castle, set the tone as early as 1931, even before the term 'modernist' was applied to the writers Wilson discusses. According to him, it was only possible to make sense of Yeats, Eliot, Joyce or Stein by considering their debts to the symbolist school that developed around Stéphane 
Mallarmé. ${ }^{4}$ Wilson's insights have been refined, adapted or challenged in various ways over the years, but even recent attempts at contextualizing English-speaking modernists still see the influence of French symbolism as a confirmation of modernism's ability to transcend national boundaries. In other words, French symbolism goes on functioning as shorthand for a residual cosmopolitanism which defines at once the limits of contextualizations of modernist texts. Thus, in the recent Locations of Literary Modernism, editors Alex Davis and Lee M. Jenkins set out to explore the tensions between modernist internationalism and modernists' engagement with the politics of place, region and nation. Yeats is mentioned as a writer who tried to fuse nationalism with symbolist poetics, but Davis and Jenkins also argue that one side of Yeats's symbolism inevitably exceeds cultural politics. Yeats may have been a consciously Irish symbolist, but his "gravitation over the 1890 s to the example of Villiers de L'Isle-Adam's Axël, and other manifestations of French and Belgian symbolism, illustrates his contrary adherence to fin-de-siècle aestheticism, and the symbolic artist's alienation from socio-political determinants." It looks as though the votaries of pure art across the Channel retain a forbidding mystical aura for English-speaking critics. Almost by definition, a debt to French symbolism confers on modernists a degree of immunity from contextualizations, even when these are explicitly encouraged. This attitude largely springs from a neglect of the critical work that has recontextualized French symbolism itself; in this particular instance, Davis and Jenkins seem to be unaware that their casual distinction between "French and Belgian symbolism" may carry more weight than is usually recognized by critics of English-speaking modernism.

That "French symbolism" is not a homogeneous category is acknowledged in commentary on its English-speaking followers, but the distinction between French and Belgian contexts is scarcely ever considered. Wilson himself pointed out that the poetics of Yeats and Eliot stemmed from different strains of French symbolism (80). Both Eliot and Yeats may have been profoundly indebted to Arthur Symons and his seminal survey The Symbolist Movement in Literature $(1899,1908)$, but whereas Yeats relied on Symons as a guide to Mallarmé, Verlaine, Villiers and Maeterlinck, Eliot was mostly interested in Laforgue and went on to (re)discover Baudelaire and Corbière. Yeats looked to symbolism for visionary intensities and a rejection of materialism that were still essentially Romantic, whereas Eliot valued the sophisticated irony of poets who were at ease with modern city life. But the contrast between Yeats's and Eliot's choices of poetic models 
was not only a question of temperament or philosophy. It can also be ascribed to the positions that different symbolist writers occupied within their respective national contexts. More particularly, Yeats's attempts at fusing Irish nationalism and symbolism can explain his interest in a Belgian writer like Maeterlinck. Far from exemplifying his "alienation from socio-political determinants," Yeats's attraction to Maeterlinck's Belgian symbolism can alert us to far-reaching similarities between the national, sociological and linguistic contexts in which their two symbolist poetics developed at the end of the nineteenth century.

There are several insights to be gained from a systematic comparison between Yeats and Maeterlinck in their Irish and Belgian contexts. (1) It can help us grasp the exact nature of Yeats's debt to Maeterlinck. Both authors have sometimes been compared as practitioners of symbolist drama, ${ }^{6}$ but little has been made of Yeats's reading of Maeterlinck's book of essays Le Trésor des Humbles (1896). This, I will argue, is the most crucial and tangible link between both writers, and it sometimes helped Yeats to qualify his debt to "French" symbolism, and more specifically to another of his "golden books," i.e. Villiers de l'Isle-Adam's play Axël. (2) Another objective is to dispel the vagueness that still surrounds references to "French symbolism" in critical accounts of English-speaking modernism, and to stress the need for a closer attention to the national contexts of French-speaking symbolism itself. So far, there has been only one (early) attempt to link Yeats and Maeterlinck through their distinctive national traditions, but the Romantic bias it displays obscures the ironies inherent in those traditions. It will be necessary to go beyond its somewhat naïve account, and take on board more recent developments in the study of late nineteenth-century Belgian and Irish literature. (3) Those developments have sometimes drawn on widely different theoretical models: if postcolonial theory has had a major impact on Irish studies, the same is not true of contextualizations of Belgian literature, for very obvious reasons. Postcolonial readings of Yeats have done much to increase awareness of his socio-cultural position within Ireland. But Yeats's resemblance to Maeterlinck should cause us to wonder whether a postcolonial paradigm is really the most useful tool in a contextual analysis of Yeats's symbolist aesthetics and politics. (4) By drawing on hitherto separate contextualizations of English-speaking modernism and French-speaking symbolism, a comparative study of Yeats and Maeterlinck in their national contexts can also provide a case study in the benefits and problems of a sociological focus for comparative literature. Indeed, although Yeats's situation in Ireland in many ways resembled Maeterlinck's in Bel- 
gium, it is probable that Yeats was largely unaware of those similarities. To what extent separate, but similar backgrounds can give rise to unsuspected affinities between the poetics of two symbolist writers, is a question that has methodological implications for our approach to European symbolism at large.

Yeats's various comments on Maeterlinck do not suggest that he ever gave much thought to the possible specificities of Belgian symbolism. Although he tactically distinguished between France and Belgium when enumerating the countries affected by the symbolist reaction against rationalism, he was otherwise happy to discuss Maeterlinck's work as part of the "French" literature that had sprung from Mallarmé and Villiers. ${ }^{7}$ There certainly was little enough in Maeterlinck's plays to alert audiences to the author's Flemish origins. In his review of Aglavaine et Sélysette, Yeats was struck by the ethereal remoteness of the characters: "we do not know in what country they were born, or in what period they were born, or how old they are, or what they look like." ${ }^{\prime}$ Yeats's response to Maeterlinck's drama may thus seem to be of a piece with his interest in an art that transcended all secular considerations. Some of Yeats's own plays can remind one of Maeterlinck's in their mediaevalism, the attention paid to setting, the use of certain themes, or their atmosphere of mystery and menace. ${ }^{9}$ It is probable that Yeats underwent some influence, but his first plays were planned before he discovered Maeterlinck..$^{10}$ Parallels between The Countess Cathleen and La Princesse Maleine or L'Intruse are a result of confluence as much as influence, which for Yeats would no doubt confirm his theory about the spontaneous rise of a new symbolic art across Europe.

Such similarities also gave one contemporary an opportunity to relativize the importance of race theories. The dramatist William Archer, noting the "strong spiritual affinity between the two poets," observed that "Mr Maeterlinck, as a Fleming, is presumably of Teutonic origin; while $\mathrm{Mr}$ Yeats, as we know, is a Kelt of the Kelts [sic]." After speculating that "some single far-off Keltic ancestor [...] lives again, by a freak of atavism, in $\mathrm{Mr}$ Maeterlinck," Archer finds it safer to conclude that "as a foundation for theories of the artistic temperament, blood is little thicker than water."11 Enlightened though his remarks appear to us, Archer is in fact reading both authors against the grain. Maeterlinck's "Teutonic" qualities may not have been much in evidence in his plays, but he himself certainly strove for an art that was "Germanic" in spirit. If Archer's comparison can hold, it is partly because Maeterlinck's definition of Germanic art was large enough to accommodate English sources, like the poetry of Morris and Dante Gabriel Rossetti or pre-Raphaelite painting, which harked back to North- 
ern medieval legends. ${ }^{12}$ Yeats was of course indebted to the same English sources, the only difference being that he stressed their rediscovery of the Celtic material which was central to his own aesthetics. ${ }^{13}$ Racial thinking among symbolists like Yeats and Maeterlinck was clearly no obstacle to the forging of links between "men of two races which it is the fashion to regard as diametrically antagonistic" (Archer 129). Whether this was enabled by Maeterlinck's cultivated vagueness, a common debt to the medievalism of Morris, the mysterious workings of a "spirit of the age" that was resolutely cosmopolitan, or the more subtle form of cultural politics which will be considered below, Yeats could certainly find much in Maeterlinck to suit his own needs as a playwright.

For all that, Yeats was never completely convinced by Maeterlinck's drama. His review of Aglavaine et Sélysette (1897) already voiced some misgivings: "the first act and part of the second act are a little absurd, because Meleander and Aglavaine explain when they should desire and regret" (53). As the 1890s turned into a new century, the theatre would give Yeats further reasons to part company with Maeterlinck. Yeats became increasingly dissatisfied with the insubstantiality of Maeterlinck's characters, their abstraction and their lack of a "ceaseless reverie about life which we call wisdom." ${ }^{14}$ When Yeats did exploit the possibilities of Maeterlinck's drama, he drew his characters more sharply and gradually gave specific cultural connotations to the sense of brooding menace that Maeterlinck associated with death, spiritual yearnings or unseen forces. If Yeats originally defended The Countess Cathleen (1898) against interpretations that set his play in a given period of Irish history (Flannery 124), his drama soon became explicitly nationalist. In Catbleen ni Houlihan (1902), the mysterious female intruder who disturbs the characters' domestic quiet is Ireland herself, a spiritual force calling on the courage of her sons to fight for her freedom. Meanwhile, Maeterlinck's drama developed in directions that would prompt Yeats to complain about "melodrama and spectacle." 15

The "continual reverie about destiny" that was lacking in Maeterlinck

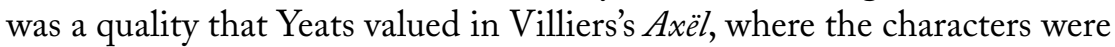
"lifted above the pride of the world [...] by hidden and august destinies." As a playwright, Yeats remained closer to Villiers. But as far as philosophy was concerned, Maeterlinck's Le Trésor des Humbles was at least on a par with Axël in Yeats's esteem. Yeats thought that if Maeterlinck "could make his persons speak out of its wisdom," it would "make his plays more beautiful in time." 16 Those hopes remained unfulfilled, but Le Trésor des Humbles did have an impact on Yeats in its own right. And in some respects, its influence was more profound than that of Axël. At the turn of the century, 
both works were two "golden books" for Yeats, who used them as guides into mysticism and esotericism. The main philosophical difference between Axël and Le Trésor des Humbles is quite obvious: while Villiers exalts the otherworldliness of a doomed and haughty aristocrat, Maeterlinck discerns spiritual immanence in the minutest details of ordinary lives. Yeats could be attracted by either position; the reason why he eventually sided with Maeterlinck has much to do with the resemblance between Maeterlinck's relation to fin-de-siècle Belgian cultural politics and Yeats's own position within Ireland in the troubled years that followed the fall of Charles Stewart Parnell in 1891.

For a long time, the spread of symbolism seemed to be an object lesson in literary internationalism. Pioneers of comparative literature commented that "for the first time and until now for the only time in the universal history of literature, a literary school propagate[d] its influence on the entire planet." The success of symbolism showed that "art ceased in truth to be national and assumed the collective premises of Western culture. Its overwhelming concern was the non-temporal, non-sectarian, non-geographic, non-national problem of the human condition." ${ }^{17}$ The impact of symbolism could however vary according to national circumstances. In both Ireland and Belgium, symbolism also coincided with the emergence of a full fledged national literary culture. Unlike France or England, Belgium and Ireland had until then lacked a proper literary scene of their own, and Romantic stirrings in the nineteenth century had either remained inchoate or been suppressed. There had of course been pioneers of national literature earlier in the century: one can cite Charles de Coster, author of the nationalist novel La Légende d'Ulenspiegel, in Belgium; as for Ireland, Young Irelanders like Thomas Davis, isolated geniuses like James Clarence Mangan, and antiquarians like Ferguson were celebrated with some jealousy by Yeats in his programmatic "To Ireland in the Coming Times." But Maeterlinck and Yeats saw themselves as belonging to the first generations of writers who were part of a structured national cultural scene that they helped to set up. The rise of a national literature in both countries meant that fin-desiècle symbolism would go hand in hand with nationalism and a belated form of Romanticism. This was not lost on Enid Starkie, an Oxford professor of French literature, herself of Irish origin, who drew attention to those parallels in a lecture she gave at Maeterlinck's centennial celebration in $1962 .{ }^{19}$ Perceptive though it is, Starkie's comparison remains imbued with the very Romanticism of the phenomenon it describes. Starkie's rheto- 
ric, in fact, betrays a Yeatsian perspective on the rise of Irish cultural nationalism, which she also projects onto Belgian literary history.

"Quand naquit Maeterlinck en 1862" ["When Maeterlinck was born in 1862"], Starkie writes, "Belgium," although independent for a generation, "n'était pas encore devenue consciente de ses responsabilités littéraires nationales" ["was not yet aware of its literary responsibilities as a nation"] (73). Half a century later, in 1911, Maeterlinck's then considerable reputation culminated in the Nobel Prize for literature. This rewarded the efforts of one of those who had tried, since the 1880s, to create a Belgian literature and put it on the world map. To achieve this, Maeterlinck had cultivated his difference from France. Although he wrote in French, he did not regard his work as part of French literature-his exaltation of Germanic art partakes of that strategy. He also took a quasi-Romantic interest in popular culture, i.e. Flemish folk songs and legends. In all these respects, Starkie points out, he foreshadowed Yeats and the Celtic revival:

A la fin du XIXe siècle [...] les écrivains d'Irlande, bien qu'écrivant en anglais, voulaient être considérés comme des écrivains irlandais, voulaient exprimer les sentiments les plus profonds de leur raceleurs rêves, leurs intuitions et leurs aspirations. C'est alors qu'eut lieu la Renaissance irlandaise. Ils se tournèrent alors vers l'étranger plutôt que vers l'Angleterre pour leur inspiration, et les écrivains par lesquels ils furent le plus influencés furent Villiers de l'Isle-Adam et Maeterlinck. (91)

[At the end the $19^{\text {th }}$ century ... Irish writers, although they wrote in English, wanted to be considered as Irish writers; they wanted to express the deepest feelings of their race - their dreams, their intuitions and their aspirations. That is when the Irish Revival occurred. They then turned abroad rather than to England for inspiration, and the writers who influenced them most were Villiers de L'IsleAdam and Maeterlinck.]

Et ces écrivains irlandais, voyant dans la littérature de langue française, la révolte des écrivains belges qui écrivaient en français mais qui étaient d'une autre race et d'une autre tradition, ces Irlandais se voyaient maintenant comme appartenant à un autre groupe, une autre civilisation. (93) 
[And those Irish writers, seeing in French-speaking literature the rebellion of Belgian authors writing in French but who were of another race and another tradition, those Irish writers now saw themselves as belonging to another group, another civilization.]

Starkie should certainly be credited with an original insight, which has unfortunately been neglected in subsequent discussions of Yeats and "French symbolism." But her Romanticizing account smooths over several problems which have more recently been highlighted in separate studies of the Belgian and Irish revivals. The literary nationalisms that Starkie celebrates concealed certain political tensions that also helped shape the philosophy and the aesthetics of their practitioners (as well as the rhetoric of their critical champions). My aim here is to show that a comparison of those tensions in Yeats and Maeterlinck can help illuminate the reassessments of both traditions. Belgian and Irish versions of symbolism were more complex than Starkie acknowledged, but their very complexities can still prove suggestively similar, holding lessons for each other and for a refined typology of European symbolism.

What makes Belgian and Irish varieties of symbolism so alike is more than chronology and the cultivation of literary nationalism in emerging, peripheral European nations. ${ }^{20}$ That literary nationalism was in fact complicated by the symbolist writers' positions within the social and linguistic divides of both Belgium and Ireland. Its relation to political nationalism was also more problematic than Starkie's vibrant but simplifying formulae allow. Before we explore those similarities, a reminder about some basic historical differences is in order. Not only was Belgium already a nation by the time Belgian symbolists proclaimed their literary independence from Paris, but the 1830 revolution had been directed against Dutch (and not French) rule. In Ireland, by contrast, Yeats and his colleagues largely launched their effort at creating an Irish literature after hopes for Home Rule had been given a blow by the fall of Parnell. Yeats gave his version of events in his Nobel Prize acceptance speech:

The modern literature of Ireland, and indeed all that stir of thought which prepared for the Anglo-Irish war, began when Parnell fell from power in 1891. A disillusioned and embittered Ireland turned from parliamentary politics; an event was conceived, and the race began, as I think, to be troubled by that event's long gestation. ${ }^{21}$ 


\section{YEATS, MAETERLINK, AND CULTURAL NATIONALISM}

In the Irish case, the ruling power and the cultural metropolis also coincided: it was England. The fortunes of European nationalist movements are clearly not the best guide in a comparison between the Belgian and Irish symbolist movements; similarities are in fact the result of more specific sociological factors to which we now turn.

In Yeats's retrospective account, the Irish revival was to be regarded as a continuation of nationalism by other means after politics had failed to deliver for Ireland. This version of the revival was long influential (as Starkie's comments still show), but it has recently been challenged by critics who have queried the exact nature of Yeats's nationalism. ${ }^{22}$ The writers of the revival explicitly aimed at fostering an Irish national culture that was independent from London, but their support for political nationalism was far from straightforward. Yeats's version of Ireland in the 1890s plays down the extent to which nationalist politics remained active after the fall of Parnell, it also masks his own alienation from the realities of political nationalism. ${ }^{23}$ A eulogist of Ascendancy power, Yeats was at best ambivalent about the prospect of an independent Ireland that would be dominated by the Catholic middle classes. His celebrations of an Ireland of peasants and aristocrats thus excluded the main driving force behind nationalist agitation after the demise of Parnell. Furthermore, Yeats's interest in Irish peasant folklore and his reliance on local, popular legends was undoubtedly a form of Romantic, cultural nationalism, but it did not necessarily imply an alliance with nationalist politics. The cultivation of home-grown Irish virtues had also been encouraged by various British intellectuals who argued that cultural diversity would be all benefit to the United Kingdom of Great Britain and Ireland. Matthew Arnold was the best example of an admirer of Celtic culture who was also an ardent Unionist; and he looms large behind Yeats's own thinking about the Celtic mind. ${ }^{24}$ That the rediscovery of that Celtic mind should imply an interest in magic, mysticism and the occult, as well as a concomitant symbolist aesthetics, only helped Yeats to eschew the pragmatic questions of nationalist politics.

When Yeats turned to Maeterlinck, he found a symbolist who also praised the wisdom of the people, and of the peasants in particular. Maeterlinck hailed from Flanders, which unlike the industrialized South of Belgium was still largely a rural, agricultural society not so different from Ireland. Born into the landowning (and French-speaking) bourgeoisie of Ghent, Maeterlinck actually approximated to Yeats's own idealized version of an Irish aristocracy that was spiritually close to its Celtic tenants. Most Belgian symbolists had a similar, French-speaking Flemish background, 
although some of the younger representatives came from the lower middle classes. ${ }^{25}$ Maeterlinck's interest in Flemish folklore, and by extension in a "Germanic" culture that embraced England, Scandinavia and Germany as well as Flanders, was part of a wider sense among Belgian symbolists of belonging to the "North" - which also included Celtic fringes like Scotland. ${ }^{26}$ This emphasis on a mystic "Northerness" enabled Belgian symbolists to stress their differences from a French literary culture that was irredeemably Latin and classical; ${ }^{27}$ it simultaneously expressed their alienation from that section of the Belgian middle classes which pursued the material successes of an industrializing economy at the expense of cultural and spiritual aspirations. The creation of a Belgian symbolism that cultivated Flemish virtues was thus an act of purely cultural nationalism which, unlike political nationalism, set itself explicitly against the economically powerful elements within the middle classes. These elements had already won their fight when Belgium became a nation in 1830; the cultural nationalism of the symbolists had nothing to do with demands for political independence. In other words, its relation to politics was more a matter of class than of national identity.

If Yeats's affinities with Maeterlinck betray the similar nature of their respective nationalisms, they tend to confirm that the Irish revival bore a most indirect relation to Irish nationalist politics. In both cases, literary nationalism should be partly construed as a way of voicing dissent with middle-class culture (or the perceived absence thereof). Moreover, if "national" qualities actually amounted to rural and mystical virtues as opposed to middle-class philistinism, it is little wonder that the "Teutonic" side of Maeterlinck and the "Keltic" side of Yeats bore an uncanny resemblance to each other. The explanation is not that the symbolist temperament magically transcended the bonds of race and blood, but that the sociological convergences of symbolist movements in Ireland and Belgium were bound to produce similar results, and were likely to facilitate the process by which Yeats came under the spell of Maeterlinck's philosophy.

The chronology and internal structures of Belgian and Irish varieties of symbolism suggest further similarities. In both cases, the rise of an organized literary movement occurred when social and/or political crises marginalized the young men who would become the leading figures of homegrown symbolism. Yeats's tendency to identify with the Irish aristocracy was a compensation for his comparatively humble, Protestant, middle-class origins, which occasionally bred a sense of economic and social insecurity. This insecurity was of course increased by the cultural and political threat 
represented by the rise of the Catholic middle classes. When Yeats arrived on the scene, the fall of Parnell seemed to bar the way to militant nationalism for Protestants-hence Yeats's diagnosis of the 1890s as a decade altogether wasted for political nationalism. For a whole sector of the Protestant intelligentsia, cultural nationalism had become the only way to stake out a prominent place in Irish life. Yeats threw himself with remarkable energy into a literary career, and contributed feverishly to Dublin-based journals that seemed more eager for cultural news in the wake of political debacle, thus providing an Irish forum where the revival could attract notice. ${ }^{28}$ Likewise, Belgian symbolism first arose in the 1880s, when there was a general disaffection with "politics," i.e. the relentless, bitter ideological warfare waged by the Liberal and Catholic parties round issues like education. More crucially, a recent economic downturn in the 1870s and the resulting budget problems for the government had compromised the careers of many university-educated sons of the bourgeoisie. Maeterlinck and many other Belgian symbolists had degrees in law that, in better circumstances, might have given them access to comfortable careers at the bar or in the civil service. ${ }^{29}$ Although it was not as highly organized as later avant-garde movements, Belgian symbolism arose as a group of dissatisfied young intellectuals. Literary journals mushroomed, providing the infrastructure through which Belgian symbolism would develop independently from the Paris scene. In their sociological origins, their personnel and the logistics on which they depended, the Belgian and Irish movements offer many points of fruitful comparison.

As products of a disaffection with the uninspiring realities of politics and economics, Belgian and Irish symbolists may not be so different from their counterparts in France or elsewhere. What links them in their specificity is that this disaffection led not just into aestheticism, but also into an alternative nationalism where culture was central. Whereas Villiers or Mallarmé retreated into the isolation of l'art pour l'art, both Irish and Belgian symbolists sought an alliance with a peasantry that appeared socially and culturally different from the middle classes. Their belatedly Romantic cultivation of national roots was part of a search for a new synthesis of which their art was the vanguard. The incarnations of that synthesis were as various as they were vague. But whether they contemplated a regenerated nation, the kingdom of God, or socialism, Belgian and Irish symbolists shared a utopian strain that is largely absent in the French variety. Their symbolist utopias are even more remarkable in that they could re-absorb the middle classes themselves into a whole where immemorial, spiritual values would reign supreme. 
This utopian desire runs throughout Le Trésor des Humbles, which is also a prophecy of the spiritual age that would succeed a most bourgeois century. Maeterlinck's favorite founts of wisdom were humble peasants whose souls harboured truths deeper than those found in Racine (32); by contrast, he openly mocked the spiritual barrenness of the middle classes. Maeterlinck thus observed "au fond d'une ville morte, le bourgeois sans espoir qui me parle de sa rue, de son mariage ou de son industrie" (97) ["at the end of a dead city, the hopeless bourgeois who talks to me of his street, his marriage, or his business"]. But he also made it clear that, in the end, every soul has the same potential, whether it belongs to the artist, the peasant or the bourgeois. This pits Maeterlinck directly against Villiers, whose aristocratic pride made no allowances for dim, inferior creatures below his station. To a certain extent, Yeats did value that pride, finding it dramatically more effective than the helplessness of Maeterlinck's characters, and perhaps also congenial to his definition of the Irish Ascendancy mind. U1timately, though, Yeats sided with Maeterlinck in thinking that every human being was blessed with spiritual immanence. This was not only true of the symbolist artist, the nobility or the peasants who were mystically at one with the secret of the universe. It was also true of the bourgeois whom the French aristocrat Villiers happily consigned to oblivion. In The Symbolist Movement in Literature, Symons had taken Villiers to task for his spiritual exclusiveness: Villiers, Symons writes, "does not realise, as the great novelists have realised, that stupidity can be pathetic, and that there is not a peasant, nor even a self-satisfied bourgeois, in whom the soul has not its part, in whose existence it is not possible to be interested." ${ }^{30} \mathrm{It}$ is difficult (and perhaps unnecessary) to try and determine whether Symons influenced Yeats, or if Yeats's own thinking guided Symons's pen in his comments on things spiritual - in his preface to The Symbolist Movement in Literature, Symons bows to Yeats's superior knowledge of mysticism. ${ }^{31}$ In any case, both had read Le Trésor des Humbles with deep interest. Symons's last chapter is devoted to "Maeterlinck as a Mystic," and it is of course Maeterlinck, more than the "great novelists," who insisted on the hidden life of the soul in every man. And it is Maeterlinck's version of a low-key, but all-embracing mysticism that Yeats later echoed in 1913. With Romantic Ireland dead and gone, and his own work for the theatre and the arts in Ireland defeated by indifference or hostility, Yeats made a last-ditch attempt at reaching out to the Irish middle classes by acknowledging their spiritual potential: 
Indignant at the fumbling wits, the obscure spite

Of our old Paudeen in his shop, I stumbled blind

Among the stones and thorn-trees, under morning light;

Until a curlew cried and in the luminous wind

A curlew answered; and suddenly thereupon I thought

That on the lonely height where we are all in God's eye,

There cannot be, confusion of our sound forgot,

A single soul that lacks a sweet crystalline cry.

(The Poems 161)

The theme and final image of "Paudeen" recall those passages in Le Trésor des Humbles where Maeterlinck stresses that in the eyes of eternity, every soul is a gem in its own right:

Lorsque Jésus lit les pensées misérables des Pharisiens qui entourent le paralytique de Capharnaüm, êtes-vous sûr qu'il juge aussi leur âme d'un coup d'oeil analogue, qu'il la condamne en même temps et qu'il n'aperçoive pas, par delà ces pensées, une clarté inaltérable? ... La pensée la plus basse ou l'idée la plus noble laissera-t-elle une trace sur le pivot de diamant? (48)

[When Jesus reads the miserable thoughts of the Pharisees who gather round the cripple at Capernaum, are you sure that he also judges their souls in the same glance, that he condemns at the same time and that he does not perceive, beyond those thoughts, an eternal brightness? ... Will the lowest thought or the loftiest idea leave a trace on the diamond pivot?]

For Yeats as for Maeterlinck, "rien ne se perd dans une âme, et [...] les plus petites ont aussi leurs instants de splendour" ["nothing is ever lost in a soul, and [...] the lowliest also have their splendid moments"] (Le Trésor des Humbles 160).

One should not of course exaggerate the compassion that Irish and Belgian symbolists could feel for the middle classes. Most of the time, the bourgeois came in for a criticism which was as intense as the symbolists' admiration for the homely virtues of peasants. The poets' relation to that peasantry, however, came up against a fact that added a further twist to their "nationalist" interest in popular wisdom. Indeed, Irish and Belgian symbolists used languages other than those of the country folk whose lore 
they studied. They were both determined to turn that linguistic gap to aesthetic and political advantage: by drawing on a folk culture whose language was alien, they championed a symbolism that advertised its national difference and defamiliarized the metropolitan language in which it was written. If Mallarmé distorted the French language through over-subtlety of thought, Belgian symbolists could do so more simply by flaunting Belgicisms and letting Flemish patterns influence their syntax. ${ }^{32}$ It was also Yeats's ambition to create a poetic language that would alienate English from metropolitan rhythms and diction, and the source of that transformation was the influence of the Celtic tradition. Synge's plays, drawing as they did on the speech idioms of West country peasants, probably constitute the best-known and most successful example of that endeavour. According to Yeats, "the use of Irish dialect for noble purposes by Synge [...] has done much for national dignity." He also recalled how Synge used to claim, with regard to his Playboy of the Western World, that "the wildest sayings in this play are tame indeed compared with the fancies one may hear at any little hillside cottage of Geesala, or Carraroe, or Dingle Bay." ${ }_{33}$

Nonetheless, the cultivation of that linguistic otherness clearly had its limits, which also marked the limits of the symbolists' nationalist pretensions. Irish and Belgian symbolists stopped short of actually writing in Gaelic or Flemish. As with regard to political independence, the historical developments regarding the language situation in Ireland and Belgium offer some significant differences. Gaelic had already entered what would be an all but terminal decline in much of Ireland by the time Yeats and his colleagues at the Abbey Theatre exploited its possibilities. Yeats himself never learned to speak Gaelic; he largely regarded it as a substratum that influenced Irish English, and was content to foreground that influence in the dramatic practice of the Abbey Theatre. Flemish, on the other hand, was still the language spoken among the lower classes in Flanders, it was later gradually established as its sole official language, and became the instrument of a political agitation that undermined the unitary nature of the Belgian state. Maeterlinck himself knew enough Flemish to plead some minor cases in the language during his early years as a lawyer; he also translated the writings of the mediaeval Flemish mystic Jan van Ruysbroeck (whom Yeats would read in his turn). Ruysbroeck's Flemish, according to Maeterlinck, belonged to languages that were "presque immémorielles" [almost immemorial], so that the mystic had at his disposal a language where "les mots sont réellement des lampes derrière les idées" ["words really are lamps behind ideas"]. But when it came to artistic expression, Maeterlinck himself 
stuck to French-even though his admiration for a novelist friend who wrote in Flemish shows that he considered the language as a worthy medium for contemporary literature. ${ }^{35}$

Yeats and Maeterlinck, however, are still similar in that they both considered the local, "native" tongue as the exclusive property of an idealized lower class, or as a source of inspiration that chiefly helped poets revitalize a stilted metropolitan language. Crucially, they defended the idea that Gaelic and Flemish were dialects - with different degrees of vitality, to be surewhich it would be a folly to codify and organize in order to challenge the position of English or French. Despite various declarations of support for the revival of Gaelic, Yeats could also distrust the efforts of the Gaelic League, especially when it promoted the active use of Gaelic in everyday life throughout Ireland. Not only did he probably feel, as an English-speaker, that Gaelic was a lost cause, but he also disapproved of the growing influence of political nationalists in circles that defended Gaelic. He thought that plays in Gaelic were often mere propaganda where artistic effort was too obviously lacking. Most of all, he complained that the League's efforts to make Gaelic fit for communication in a modern Irish nation disfigured the purity of the language: they were "infecting Irish not only with English idiom but with the habits and thoughts of [...] journalism, a most un-Celtic thing." ${ }^{36}$ Maeterlinck, for his part, deeply shocked Flemish nationalists when he condemned efforts at unifying Flemish dialects into a language that would dislodge French from its official status in Flanders. His reputation as a fransquillon (French-speaking Flemish bourgeois) has stuck to him ever since. Maeterlinck's fusion of symbolism and Belgian cultural nationalism relied on Flemish difference. But in the same way that Yeats could distinguish between cultural nationalism and calls for political separation, Maeterlinck argued that Flemish difference should not be taken so far as to undermine the French-speaking Belgian state. And, like Yeats, Maeterlinck complained about the artificiality of the radical nationalists' linguistic agenda: turning the dialects of the people into an single, official language would only debase those beautiful idioms into a "jargon vaseux" [muddy jargon]. ${ }^{37}$

The linguistic otherness of folk culture was eventually a source of both inspiration and anxiety for Yeats and Maeterlinck. Their gateway into ancient lore could also be turned by others (often of lower middle-class origin) into a political tool in the pursuit of nationalist ends far more radical than theirs. This paradox had aesthetic implications as well. The poetic languages of Irish and Belgian symbolism oscillate between the defamiliarization inspired by popular dialect, and the almost Mallarméan 
temptation of silence or of a Yeatsian "tongue men do not know" (The Poems 53). ${ }^{38}$ But if Yeats and Maeterlinck were alike in their nationalist subversion of the idiom they wrote in, their shared distrust of human communication was not just Mallarméan. Whereas Mallarmé's silences and esoteric utterances resulted from a self-imposed aestheticist isolation, their equivalents in Yeats and Maeterlinck did not always imply a retreat into solipsism. Rather, they could also be the medium for an alternative and deeper form of understanding - an understanding that would, among other things, connect the poet with common folk. The fact that those common folk did not actually speak the language of the poets in the first place gave added relevance to a rejection of normal communication. In Le Trésor des Humbles, Maeterlinck insisted on silence as a condition for genuine communication between souls. True communication did not require words:

La paysanne à qui je demande mon chemin, je la juge aussi profondément que si je lui demandais la vie de ma mère, et son âme m'a parlé aussi intensément que celle de ma fiancée. Elle remonta, en hâte, jusqu'aux plus grands mystères, avant de me répondre; puis elle m'a dit tranquillement, sachant tout à coup ce que j'étais, qu'il fallait prendre à gauche le sentier du village. (Le Trésor des Humbles 79)

[That peasant woman from whom I ask my way, I judge her as profoundly as if I asked my mother's life from her, and her soul has spoken to me as intimately as my fiancée's. She quickly reached back to the deepest mysteries before she answered me; then she told me quietly, knowing suddenly what I was, that I should take the village path on the left.]

Maeterlinck's belief in silent communication cannot be wholly ascribed to anxieties about linguistic difference. Maeterlinck held that silence could also be preferable in the presence of lovers or close relatives; he also knew enough Flemish to get by in the presence of peasants, which gave him an edge over Yeats. But for both writers, mystical communion solved any problem caused by the gap between their symbolist art and the language of their popular sources. ${ }^{39}$ Yeats's and Maeterlinck's preference for a mystical understanding with "ordinary country people" allowed them to sidestep both the practical problems of linguistic difference, and the demands that political nationalists made on behalf of the same people and their language. 


\section{YEATS, MAETERLINK, AND CULTURAL NATIONALISM}

Yeats's interest in Maeterlinck points to parallels that can define a new typology of European symbolism. This typology includes a "peripheral symbolism" that was articulated round the social, cultural and linguistic tensions affecting two relatively marginal nations. This peripheral symbolism is chiefly characterized by the residual Romanticism of its interest in folklore, its complex cultural nationalism, the peculiar nuances of its opposition to the bourgeoisie, and its ambivalent cultivation of linguistic otherness. Its relation to "mainstream" symbolism was one of both profound indebtedness and deliberate distance, which could go as far as relatively overt criticism.

Despite the often touted international nature of symbolism, the distinction between those two strains is real enough. Moreover, it does not result solely from the cultural nationalism of Belgian and Irish symbolists. Peripheral symbolists liked to define themselves in opposition to the culture of the metropolis, but some metropolitan symbolists could also express a marked hostility towards the aesthetics and the cultural politics of peripheral symbolism. If T.S. Eliot was always closer to French (as opposed to Belgian) symbolism, it was not simply because his own preoccupations were those of an insecure cosmopolitan dandy with a philosophical training. Eliot's own preferences among continental symbolism are also part of a consistent form of cultural and national politics. Long before his naturalization as a British subject and his conversion to Anglicanism, Eliot was already an outspokenly metropolitan writer who had little time for Yeats's Celticism. His criticism of Yeats was not only motivated by a dislike of late Romantic vagueness or of the excesses of nineties decadence. As early as 1919, Eliot wrote Yeats off as being beyond the pale. In a review entitled "A Foreign Mind," Eliot commented that "the difference between Yeats's world and ours is so complete as to seem almost a physiological variety, different nerves and senses. It is therefore allowable to imagine that the difference is not only personal, but national." ${ }^{40}$ Those words may sound surprising, coming as they do from the rootless poet who was still to write The Waste Land. But his outlook was in fact quite coherent, given the brand of symbolism that he had cultivated since reading Symons's The Symbolist Movement in Literature in 1908. Eliot's cosmopolitanism was always metropolitan; from the start, Eliot sought to redefine England and its poetry as part of a European tradition that was Latin, classical and imperial in nature, ${ }^{41}$ and whose models would be Dante, Southern European mystics like John of the Cross (and not Ruysbroeck), and French, or even more specifically "Mediterranean" symbolists like Paul Valéry. This tradition excluded the Northern, 
Romantic and nationalist strain that connected the various writers whom Eliot dismissed, i.e., the English Romantic visionaries and the Victorian mediaevalists whom Yeats and Maeterlinck took as models, down to Yeats and Maeterlinck themselves. Yeats's Celtic mythologizing came in for harsh criticism in After Strange Gods, and even Eliot's later praise of Yeats still shows a marked impatience with the "Yeats of the Celtic Twilight," who "uses Celtic folklore as William Morris uses Scandinavian folklore." ${ }^{42}$ Eliot chiefly criticized Maeterlinck on account of his deficiencies as a dramatist, but in a 1930 review of Peter Quennel's Baudelaire and the Symbolists, Eliot praised Quennel for going beyond Symons's survey of symbolism and "omitting [...] very rightly, Maeterlinck.” Maeterlinck's international reputation had already paled by then, but Eliot's dismissal of Maeterlinck as a "curiosity of the fashions of popular philosophy" is significantly coupled with calls for a "post-mortem of Romanticism," and for a greater awareness of "the generally 'nordic' cast of Symbolism, with its contrast in the meridional construction of Valéry" - which Eliot himself favoured..$^{43}$ The role of those contrasts and exclusions in Eliot's synthesis of symbolism in Four Quartets is beyond the scope of this essay. But their pervasive influence in the writings of the younger, "cosmopolitan" symbolist Eliot should not be underestimated.

The mutual opposition between metropolitan and peripheral versions of symbolism reveals fault lines that run through both continental, Frenchspeaking symbolism and English-speaking modernism. Although the latter is still often assumed to owe its relative coherence to the influence of French symbolism, a study of how symbolist aesthetics operated in their national contexts shows that contrasting continental influences underscore the tensions between Irish and English variants of modernism. At the same time, such a study can also warn against a recuperation of symbolism for the purposes of national(ist) canon-building. Yeats can no longer simply be presented as an icon of Irish nationalism; as for Maeterlinck, not only has his work been long out of fashion, but the very concept of a Belgian literature, which was always problematic, has largely made way for two distinct, linguistically-defined traditions. Nevertheless, Yeats and Maeterlinck cannot easily be expelled from national(ist) canons either: outright rejections of Yeats as a "West Briton" or of Maeterlinck as a fransquillon fail to do justice to their works and their legacy. For better or for worse, Yeats and Maeterlinck cannot be overlooked in histories of literature in Ireland or Flanders. The placing (or castigating) of Yeatsian symbolism within a (post)colonial model, in particular, is fraught with theoretical problems. 


\section{YEATS, MAETERLINK, AND CULTURAL NATIONALISM}

The cultural politics of the Irish revival are increasingly discussed through postcolonial theory, but the resemblance they bear to the defining questions of Belgian fin-de-siècle literature suggests that a European perspective is at least equally valid.

The works of Yeats and Maeterlinck will go on unsettling the canons of Irish/English, Flemish/Belgian/French literature. If symbolist poetics forged alliances with cultural nationalism, the complexities of that cultural nationalism, and of its relation to nationalist politics, serve to remind us that the nation is always a contested and unstable site where social, economic, linguistic, or indeed aesthetic forces vie for influence. There is much more to symbolism than its supposed internationalism, but a comparative approach remains more than just possible. If it looks at national contexts in all their complexity, it can also be the best means of gaining a properly historical insight into symbolist aesthetics, and into the national distinctions that may or may not exist within European literature.

Katholieke Universiteit Leuven

\section{Notes}

1. Although national contexts do not always feature prominently in his approach, Peter Nicholls's Modernisms (London: Macmillan, 1995) gives an idea of the challenges that have been mounted against a monolithic concept of modernism.

2. See for instance Seamus Deane, who criticizes ahistorical definitions of Anglo-Saxon modernism in Heroic Styles: The Tradition of an Idea (Derry: Field Day, 1984), and Vincent Cheng, Joyce, Race and Empire (Cambridge: Cambridge UP, 1995). Both Deane and Cheng suggest that this blindess to history plays into the hands of a cultural imperialism that sanitizes the political energies of Irish literature. John Wilson Foster makes out another case for an "Irish modernism" in Colonial Consequences (Dublin: Lilliput Press, 1991) 44-59. Scottish critics have for their part promoted Hugh MacDiarmid as a specifically Scottish modernist — see Robert Crawford's Devolving English Literature (London: Macmillan, 1994). For works on Yeats and Joyce that draw on postcolonial theory, see also David Lloyd's Anomalous States (Durham: Duke UP, 1993), Semicolonial Joyce, eds. Derek Attridge and Marjorie Howes (Cambridge: Cambridge UP, 2000), and W.B. Yeats and Postcolonialism, ed. Deborah Fleming (West Cornwall: Locust Hill Press, 2001).

3. For a recent discussion of the use of the terms in English critical discourse, see Richard Greaves, Transition, Reception and Modernism in W.B. Yeats (London: Palgrave, 2002) 4-6.

4. Edmund Wilson, Axël's Castle (London: Fontana, 1961). See particularly 25-26.

5. Locations of Literary Modernism, eds. Alex Davis and Lee M. Jenkins (Cambridge: Cambridge UP, 2000) 24.

6. The most thorough study of Maeterlinck's impact on Yeats's dramatic practice remains Katherine Worth's The Irish Drama of Europe from Yeats to Beckett (London: Athlone Press, 1978).

7. W. B. Yeats, Essays and Introductions (London: Macmillan, 1961) 187, 189. 
8. W. B. Yeats, "Review of Aglavaine et Sélysette," Uncollected Prose by W.B. Yeats, vol. 2, eds. John P. Frayne and Colton Johnson (London: Macmillan, 1975) 52.

9. Yeats's descriptions of his ideal setting for The Countess Cathleen appear to be inspired by Lugné-Poë's production of Maeterlinck's Pélléas et Mélisande. See The Letters of W.B. Yeats, vol. 2, eds. Warwick Gould, John Kelly and Deirdre Toomey (Oxford: Clarendon Press, 1997) 348. Even Yeats's last play, Purgatory, rehearses themes that appear in Intérieur, an early play by Maeterlinck that had been staged at the Abbey Theatre in 1907. See Sean Prior, “W.B. Yeats, Maurice Maeterlinck, and Old Blind Men," Yeats Eliot Review 19.4 (2002): 9-24.

10. William Archer, "From Poets of the Younger Generation," W.B. Yeats: The Critical Heritage, ed. A. Norman Jeffares (London: Routledge and Kegan Paul, 1977) 125.

11. Archer, 129.

12. See particularly Maeterlinck's early notebooks, collected as Le Cabier Bleu, ed. Joanne Wieland-Burston (Fondation Maurice Maeterlinck, 1977). Although they remained unpublished during Maeterlinck's lifetime, the notebooks give the best insight into the cult of "Germanic" qualities that occasionally surfaced in Maeterlinck's poems, plays and essays. For a definition of Germanic qualities, see 101ff. References to Morris, Rossetti and BurneJones abound throughout. The influence of late Victorian poetry on Maeterlinck has been documented by W.D. Halls in "Some Aspects of the Relationship between Maeterlinck and Anglo-Saxon Literature," Annales de la Fondation Maurice Maeterlinck 1 (n.p., 1955): 9-25.

13. In "The Celtic Element in Literature," Yeats links Irish legends to the Northern and Scandinavian material that Morris exploited. See Essays and Introductions 186-87. He also claimed that "the Irish legends, in popular tradition and in old Gaelic literature, are more numerous, and as beautiful as the Norse and German legends." See Uncollected Prose, 2: 125.

14. Quoted by James W. Flannery in W.B. Yeats and the Idea of a Theatre (New Haven: Yale UP, 1976) 123.

15. Yeats, Explorations (London: Macmillan, 1962) 257.

16. Uncollected Prose, 2: 52-53.

17. Etiemble, quoted by Anna Balakian in her introduction to The Symbolist Movement in the Literature of the European Languages (Budapest: Akademiai Kiado, 1984) 9; Anna Balakian, The Symbolist Movement (New York: Random House, 1967) 10.

18. Yeats, The Poems, ed. Daniel Albright (London: Everyman, 1990) 70-71.

19. Enid Starkie, "Maeterlinck et l'Angleterre," Annales de la Fondation Maurice Maeterlinck 8 (1962): 72-93. All translations are mine.

20. For a study of analogies between the Irish Revival and other phenomenons of cultural renaissance in a somewhat comparable European nation, see Aladar Sarbu, "Literary Nationalism: Ireland and Hungary," Literary Interrelations. Ireland, England and the World: $\mathrm{Na}$ tional Images and Stereotypes, eds. Wolfgang Zach and Heinz Kosok (Tübingen: Gunter Narr Verlag, 1987) 19-26.

21. Yeats, Autobiographies (London: Macmillan, 1955) 559. Yeats explained elsewhere that he had had "the prophecy of an intellectual movement at the first lull in politics," a "sudden certainty that Ireland was to be like soft wax for years to come" (199). For an account that relativizes Yeats's version of the revival and of his own place in it, see Yug Mohit Chaudhry, Yeats, the Irish Literary Revival, and the Politics of Print (Cork: Cork UP, 2001) 204-25.

22. The best-known attack on Yeats's nationalist credentials is Seamus Deane's Field Day pamphlet Heroic Styles: The Tradition of an Idea, which equates Yeats's cultural nationalism with a form of "literary unionism" (10). See also Spurgeon Thompson, "Yeats and Eugenicism: The Garrison Mentality in a Decolonizing Ireland," W.B. Yeats and Postcolonialism 27-50. Like Deane, Thompson essentially sees Yeats as a colonialist.

23. See Roy Foster, "Anglo-Irish Literature, Gaelic Nationalism and Irish Politics in the 1890s," Ireland After the Union (London: British Academy, 1989) 61-82.

24. For Yeats's relation to Arnold, see John V. Kelleher, "Matthew Arnold and the Celtic Revival," Perspectives in Criticism, ed. Harry Levin (New York: Russel and Russel, 1970) 
197-221, and Chris Corr, "Matthew Arnold and the Younger Yeats: The Manoeuverings of Cultural Aesthetics," Irish University Review 28.1 (1998): 11-27.

25. Maeterlinck's father was a landowner who could afford to live from his rents only-see Roland Mortier, "Histoire d'une Vie," Maurice Maeterlinck, eds. Joseph Hanse et Robert Vivier (Bruxelles: Renaissance du Livre, 1962) 15-16. For the backgrounds of other Belgian symbolists like Georges Rodenbach, Max Elskamp or Charles Van Lerberghe, see JeanMarie Klinkenberg, "Le Phénomène Jeune Belgique: Un Accident Historique?" Les Avantgardes Littéraires en Belgique, ed. Jean Weisgerber (Bruxelles: Labor, 1991) 98.

26. Maeterlinck's references to peasant lore include a discussion of Scottish peasants' use of the word "fey." See Le Trésor des Humbles (Bruxelles: Labor, 1986) 116.

27. See Herman Braet, L'Accueil Fait au Symbolisme en Belgique, 1885-1900 (Bruxelles: Palais des Académies, 1967), especially the chapter "Les Dieux du Nord et la Tradition Classique," 89-99; see also Jean-Marie Klinkenberg, "La Génération de 1880 et la Flandre," Les Avant-gardes Littéraires en Belgique 101-10.

28. For a study of Irish literary journalism and Yeats's involvement in it in the 1890s, see Chaudhry, Yeats, the Irish Literary Revival, and the Politics of Print.

29. For an analysis of the reaction to political quarrels, see Raymond Vervliet, "Les Précurseurs," Les Avant-gardes Littéraires en Belgique 41. For an analysis of the effects of the economic crisis, see Klinkenberg, "Le Phénomène Jeune Belgique: Un Accident Historique?" 96-97.

30. Arthur Symons, The Symbolist Movement in Literature (New York: Haskell House, 1971) 150.

31. For a discussion of Yeats's and Symons's mutual influence at the turn of the century, see Haskell M. Block, "Yeats, Symons and The Symbolist Movement in Literature," Yeats Annual 8 (1990): 9-18.

32. See Braet's chapter, "La Langue et le Style," in his L'Accueil Fait au Symbolisme en Belgique. In "Les Précurseurs," Vervliet enumerates the tactics used by symbolists like Maeterlinck and Elskamp: "constructions nouvelles, néologismes, archaïsmes, emprunts à la tradition populaire ... art primitif ... contes et légendes du vieux monde germanique ... tradition orale" (88) ["new constructions, neologisms, archaisms, borrowings from popular tradition ... primitive art ... tales and legends of the old Germanic world ... oral tradition"].

33. Yeats, Essays and Introductions 335, 337. Synge himself was not only adept at exploiting the Irish dialect of the West country, he also found there a truth similar to that propounded in Le Trésor des Humbles: "I felt that this little corner of the world, and the people who live in it, have a peace and dignity from which we are shut for ever" (324).

34. See Maeterlinck's introduction to his translation of L'Ornement des Noces Spirituelles, de Ruysbroeck l'Admirable (Bruxelles: Lacomblez, 1891) xxxiv-xxxv. Ruysbroeck's language would thus have met Yeats's definition of the symbol as "a transparent lamp about a spiritual flame" (Essays and Introductions 116).

35. See Maeterlinck's letters to Cyriel Buysse, quoted by Antonin Van Elslander in "Maurice Maeterlinck et la Littérature Flamande," Annales de la Fondation Maurice Maeterlinck 8 (1962): 102-03.

36. Quoted by Cara B. McClintock in "It will be very difficult to find a definition': Yeats, Language, and the Early Abbey Theatre," W.B. Yeats and Postcolonialism 208. See 206-09 for a summary of Yeats's various statements on Gaelic.

37. Quoted by Van Elslander in "Maurice Maeterlinck et la Littérature Flamande," 98-99. Maeterlinck's attitudes to French and Flemish reflected a view of linguistic roles that was widely held among Belgian cultural elites. As Klinkenberg sums up, the view was that "la première sera, à l'intérieur du pays, facteur de cohésion, à l'extérieur elle sera facteur d'universalité et d'affirmation. La seconde fournira son identité profonde à la Nation, sa profondeur historique" ["one language (French) was to be a unifying factor at home and a universal means of assertion abroad. The other language (Flemish) would confer its deeper identity and its historical depth on the Nation"]. See "La Génération de 1880 et la Flandre," 104. 
38. In Yeats's case, this hesitation partly coincides with his dual career as a poet and dramatist.

39. In Yeats's theory of symbolism, Denis Donoghue comments, symbols "are at once given and created; given, but given by creative souls not unlike our own. A race is a communion of such souls." "Yeats: The Question of Symbolism," The Symbolist Movement in the Literature of the European Languages 285.

40. Eliot's review "A Foreign Mind" is quoted by Michael Butler Yeats in "Eliot and Yeats: A Personal View," The Placing of T.S. Eliot, ed. Jewel Spears Brooker (Columbia: U of Missouri P, 1991) 172.

41. The best definition of that tradition is still Frank Kermode's The Classic (London: Faber, 1975).

42. Eliot, After Strange Gods (London: Faber, 1934), and his 1940 essay "Yeats," Selected Prose of T.S. Eliot, ed. Frank Kermode (New York: Farrar, Straus and Giroux, 1975) 252.

43. Eliot criticized Maeterlinck's plays in The Sacred Wood (London: Methuen, 1928) 6667 and 84. His review of Quennel appeared in The Criterion 9.35 (1930): 357-59. One should also note Eliot's statement that he was "not in close sympathy with Flemish art" after a visit to Bruges and Maeterlinck's native Ghent: "Flanders on the whole I don't care for." See The Letters of T.S. Eliot, vol. 1, ed. Valerie Eliot (London: Faber and Faber, 1988) 41. Eliot's affinities with Charles Maurras are also relevant here, since Maurras's French disciples cultivated a Latin spirit and were explicitly hostile to the "Northern" Maeterlincksee Henri Clouard, "Jugements Français sur Maurice Maeterlinck," Maurice Maeterlinck 495. 